\title{
The relevance of the information about intangibles:
}

\section{Some determinants}

\author{
Houneida Ben Brahim, PhD (Corresponding Author) \\ Assistant in the Higher Institute of Finance and Tax System of Sousse, Tunisia \\ Email: ben_brahim_houneida@yahoo.com \\ Mounira Ben Arab, PhD, Professor, \\ Higher Institute of Management of Tunis, Tunisia \\ Email: mounira_benarab@yahoo.fr
}

Received: February 12, 2012 Accepted: April 25, 2012 DOI: 10.5296/ijafr.v2i1.1665

\begin{abstract}
This study treats the issue of the relevance of the accounting information about intangibles (assets and expenditures). Our findings show that the relevance is found and determined by the introduction of other information. This information represents the financial constraints as motivation of manipulation and the implication degree of managers due to granted stocks options. Under low level of financial constraints, the investor judges that the value of intangibles assets recognized in the balance sheet is reliable but this information remains widely insufficient to modify its valuation. However, this low level transmit to the market a signal of the failure of the R\&D projects because it is predicted that these projects will be unable to realize sufficient future cash flows to honor the financial commitments of the company. Besides, we found that the information about recognized intangible assets and R\&D expenditures is well appreciated by the market for the firms which grant more stocks options. So, the granting of stocks options represents a signal to the market on the efficiency of the managers and their implication in the risk of the committed investments.
\end{abstract}

Keywords: Intangible assets - R\&D expenditures - Relevance - Financial constraints Stocks options - Managers 


\section{Introduction}

In the developed markets, the economic value of a company reflects, for a large part, its intangible assets. In front of this type of assets which is in continuous growth, the traditional accounting systems carry out more and more difficulty to insure their informative role in the decision-making process. In fact, the principle of reliability is often privileged by the accounting regulators than the principle of relevance. As a result, the information contained in financial statements cannot explain a direct relation linking the accounting data to the market value of the assets of the company (Ohlson, 1995). This situation shows that the real problem of the investor is the information asymmetry with the management of the company. Information is relevant if it is capable to confirm or change the predictions of the decision makers. Thus, the relevance of financial statements represents their capacity to confirm or to modify especially the predictions of the investors. So, if the shares are negotiated between the investors, the market price will synthesize their valuable prediction. Consequently, the relevance of financial statements can be measured, on one hand, by the degree of the response reflected in the market price or in the transaction volume of during the divulgation and, on the other hand, by their capacity to explain the variations in the shares prices or the transaction volume. In this sense, the empirical researches present some evidences, but are not decisive, concerning the decrease of the relevance of the accounting earnings. A part of this decrease results from a lack in the recognition of the intangible assets in the balance sheet. These studies on the relevance of the accounting information provide the utility to the accounting regulators in the examination and the elaboration of accounting standards.

This paper is organized as follows: Section 2 elaborates on the literature review concerning the matter of relevance of the accounting information about intangibles and the some determinants. Section 3 presents our hypothesis and section 4 presents methodology. Section 5 discusses the empirical findings and the section 6 concludes this paper.

\section{Literature review}

\begin{tabular}{|l|l|l|}
\hline Studies & Empirical findings & Principal limits \\
\hline $\begin{array}{l}\text { Rev expenditures } \\
\begin{array}{l}\text { Zarowin } \\
(1999)\end{array}\end{array}$ & $\begin{array}{l}\text { The presence of a biais of stocks market } \\
\text { valuation of R\&D intensive firms }\end{array}$ & $\begin{array}{l}\text { The relation between the accounting } \\
\text { earnings and the stocks return is in } \\
\text { regular degradation over the period } \\
1978-1996 .\end{array}$ \\
\hline $\begin{array}{l}\text { Chan and al } \\
(2001)\end{array}$ & $\begin{array}{l}\text { A positive reaction of the shareholders to the } \\
\text { announcement of the increase of R\&D. }\end{array}$ & $\begin{array}{l}\text { This study does not establish a direct } \\
\text { relation between the level of the R\&D } \\
\text { expenditures and the future stock } \\
\text { returns }\end{array}$ \\
\hline $\begin{array}{l}\text { Lev and al } \\
(2002)\end{array}$ & $\begin{array}{l}\text { The searchers made adjustments on the } \\
\text { accounting figures by the capitalization of } \\
\text { the R\&D expenditures. Thus, they adjusted } \\
\text { the accounting earnings and the }\end{array}$ & $\begin{array}{l}\text { A considerable improvement of the } \\
\text { relation between the market price and } \\
\text { the adjusted values. }\end{array}$ \\
\hline
\end{tabular}




\section{Ml Macrothink}

International Journal of Accounting and Financial Reporting

ISSN 2162-3082

2012, Vol. 2, No. 1

\begin{tabular}{|c|c|c|}
\hline & stockholders' equities. & \\
\hline $\begin{array}{l}\text { Ding and } \\
\text { Stolowy } \\
(2003)\end{array}$ & $\begin{array}{l}\text { The capitalization of the R\&D investments } \\
\text { does not improve the relevance of the } \\
\text { accounting figures (sample French). }\end{array}$ & $\begin{array}{l}\text { This study presents a major limit } \\
\text { because it presents a cross-sectional } \\
\text { analysis (year 2000). }\end{array}$ \\
\hline $\begin{array}{l}\text { Callen and } \\
\text { Morel (2005) }\end{array}$ & $\begin{array}{l}\text { These authors used American time series } \\
\text { data over the period 1962-1996. The } \\
\text { empirical findings do not confirm the } \\
\text { majority of the previous results. The } \\
\text { searchers found that the R\&D does not } \\
\text { affect in a significant way the market value } \\
\text { just for } 25 \% \text { of the companies of the } \\
\text { sample. }\end{array}$ & $\begin{array}{l}\text { The estimation of a time series model } \\
\text { supposes, on one hand, the existence of } \\
\text { a sufficient number of observations and, } \\
\text { on the other hand, the stationnarity of } \\
\text { these data. Only, the use of this } \\
\text { technique of estimation allows creating } \\
\text { of doubt concerning the empirical } \\
\text { robustness of the positive and } \\
\text { significant relation between the R\&D } \\
\text { and the value of the company. }\end{array}$ \\
\hline $\begin{array}{l}\text { Goodwin and } \\
\text { Ahmed } \\
(2006)\end{array}$ & $\begin{array}{l}\text { They concluded that the relevance of the } \\
\text { accounting earnings is in decrease over the } \\
\text { period from } 1975 \text { to } 1999 \text { within an } \\
\text { Australian sample of companies. Only, after } \\
\text { the exclusion from the losing companies, } \\
\text { this decrease became weak. This decrease is } \\
\text { more marked for the companies which do } \\
\text { not capitalize their intangible expenditures. } \\
\text { But, the relevance increases for the } \\
\text { profitable companies which opt for the } \\
\text { capitalization. }\end{array}$ & $\begin{array}{l}\text { The Australian context is a more } \\
\text { flexible context in the activation of the } \\
\text { immaterial and consequently the } \\
\text { empirical findings of the decrease or the } \\
\text { improvement of the relevance can be } \\
\text { attributed to the other factors other than } \\
\text { the intangible. Besides, the findings } \\
\text { relative to the profitable companies can } \\
\text { be affected by the existence of the } \\
\text { important opportunities of investment } \\
\text { and by a good management. }\end{array}$ \\
\hline $\begin{array}{l}\text { Hall and } \\
\text { Oriani (2006) }\end{array}$ & $\begin{array}{l}\text { The researchers investigated a new context. They } \\
\text { are interested in three continental countries } \\
\text { (French, Germany and Italy) over the period from } \\
1989 \text { to } 1998 \text {. For the German companies, the } \\
\text { R\&D possesses an important informative value } \\
\text { especially when there aren't potential investors. } \\
\text { But, the R\&D realized by the French and Italian } \\
\text { companies is relevant only when there isn't } \\
\text { investor possessing more than a third of the shares. }\end{array}$ & $\begin{array}{l}\text { This study did not provoke the } \\
\text { differences of posting of the R\&D } \\
\text { between these various countries and its } \\
\text { impact on the quality of the information } \\
\text { transmitted to the market. Besides, the } \\
\text { empirical findings of this study can be } \\
\text { improved if the necessary data are } \\
\text { available }\end{array}$ \\
\hline \multicolumn{3}{|c|}{ Advertising expenditures } \\
\hline $\begin{array}{l}\text { Chauvin and } \\
\text { Hirschey } \\
\text { (1993) }\end{array}$ & $\begin{array}{l}\text { The advertising expenditure has a positive } \\
\text { influence on the value of the company. }\end{array}$ & $\begin{array}{l}\text { Their analysis shows that the stocks } \\
\text { returns are more associated with the } \\
\text { advertising expenditures made by the } \\
\text { big-sized companies than the } \\
\text { small-sized companies. }\end{array}$ \\
\hline Singh and al & Advertising is negatively and significantly & This study concerns just one sector \\
\hline
\end{tabular}




\begin{tabular}{|c|c|c|}
\hline$(2005)$ & $\begin{array}{l}\text { related to the cost of the share indicating a } \\
\text { weak volatility in the market returns. }\end{array}$ & (restoration). \\
\hline $\begin{array}{l}\text { Hsu et Jang } \\
(2008)\end{array}$ & $\begin{array}{l}\text { Significant relation between advertising } \\
\text { expenditures and risk associated with the } \\
\text { stocks returns. }\end{array}$ & $\begin{array}{l}\text { This study carries the same limit as the } \\
\text { previous study. }\end{array}$ \\
\hline $\begin{array}{l}\text { Shah and al } \\
(2009)\end{array}$ & $\begin{array}{l}\text { They established a positive relation between } \\
\text { advertising expenditures and market value } \\
\text { of the company when the sample is divided } \\
\text { between manufacturing and none } \\
\text { manufacturing companies, }\end{array}$ & $\begin{array}{l}\text { This study is made due to cross-section } \\
\text { data. It's better to use panel data which } \\
\text { take into account the effects relative to } \\
\text { the characteristics of the company and } \\
\text { to the time simultaneously. This } \\
\text { technique handles certain number of } \\
\text { robustness tests which allow resolving } \\
\text { some problems relative to the } \\
\text { endogeneity of the explanatory } \\
\text { variables. }\end{array}$ \\
\hline \multicolumn{3}{|c|}{ Human resources expenditures } \\
\hline $\begin{array}{l}\text { Garcia-Ayuso } \\
\text { and al (2000) }\end{array}$ & $\begin{array}{l}\text { A significant and positive association } \\
\text { between the quality of the human resources } \\
\text { and the market value. But, the intensity of } \\
\text { the investment in these human resources } \\
\text { hasn't significant explanatory power. }\end{array}$ & $\begin{array}{l}\text { The volume of the investment in these } \\
\text { human resources does not reflect } \\
\text { inevitably the importance of the human } \\
\text { resources of the company. }\end{array}$ \\
\hline $\begin{array}{l}\text { Ballot and al } \\
\text { (2001) }\end{array}$ & $\begin{array}{l}\text { The companies which possess important } \\
\text { human resources realize more stocks returns } \\
\text { (a French sample and Swedish sample } \\
\text { observed over the period 1981-1993). }\end{array}$ & $\begin{array}{l}\text { The human resources was formulated } \\
\text { from the training expenditures. }\end{array}$ \\
\hline Lin $(2007)$ & $\begin{array}{l}\text { The human resources are positively bound } \\
\text { with the financial performance of the } \\
\text { company. This finding was made from a } \\
\text { sample established by banks observed } \\
\text { between } 1995 \text { and } 1999\end{array}$ & $\begin{array}{l}\text { The human resources are measured by } \\
\text { the ratio "human expenses divided on } \\
\text { the number of the employees ". Besides, } \\
\text { the importance of these expenses in this } \\
\text { particular sector can be explained by the } \\
\text { fact that the employees receive } \\
\text { important salaries because they work in } \\
\text { a company which makes and treats } \\
\text { money. So, for precautionary measures, } \\
\text { the employees are paid well. }\end{array}$ \\
\hline $\begin{array}{l}\text { Pentzalis and } \\
\text { Park (2009) }\end{array}$ & $\begin{array}{l}\text { The market is incapable to estimate correctly } \\
\text { the real value of the human resources } \\
\text { (American sample observed over the period } \\
\text { 1978-2002). }\end{array}$ & $\begin{array}{l}\text { The human resources were determined } \\
\text { on the basis of the number of the } \\
\text { employees and, thus, the empirical } \\
\text { finding must be interpreted with } \\
\text { precaution. }\end{array}$ \\
\hline
\end{tabular}




\section{Hypothesis}

According to our synthesis of the literature made on the relevance of the information on the intangibles and especially those relative to the accounting information supplied by annual reports, we noticed that the majority of the researches pass by an intangible revaluation which is appropriate for the research in question. Consequently, the findings of these researches cannot be generalized to predict the relevance of the accounting evaluations made by the managers (Holthausen and Watts, 2001). It would be interesting to test if the investor in the stock market takes into account this information in the stock valuation of the company. Thus, we put our principle hypothesis:

\section{The accounting information about the intangible has an informative value for the stock market.}

We should be interested in the study of the relevance of the accounting information such as it is presented by the company. This allows making recommendations and supplying an empirical support for the normalizers in order to take the necessary measures for the improvement of the accounting information and the reduction of the gap between the book value and the market value of the share (Ballow and al, 2004). The significant difference suggests that financial markets take into account some informations which do not appear in financial statements. Most of these informations are supposed to be the intangible assets.

In our knowledge, there are no researches which examined the effects of the contractual incentives on the degree of the relevance of the book values reported on the intangible investments with the exception of the study of Kallapur and Kwan (2004). These researchers studied the effect of the debts on the relevance and the reliability of the book value of the patents recognized in the balance sheet. The contracts of debts can stimulate in the managers the motivation to bias their evaluations andlor change their decisions. In fact, to reduce the conflicts of interests between the managers and the creditors, the debts contracts are generally accompanied by restrictive clauses (for example, a minimal interest coverage ratio). Consequently, when there is an alternative for an accounting treatment, the managers will be incited to choose accounting methods according to the existence of the restrictive clauses. In this sense, the recognized intangible assets can be the object of an accounting manipulation.

Besides these contracts, there are the remuneration contracts which may influence the relevance of the accounting information on the intangible. At this level, we should be interested in the effect of stocks options on the perception of the investors of the relevance of the accounting data knowing that the stocks options are a long term compensation and the intangibles is a long investment. In our knowledge, there aren't empirical researches which were made in this field. It is predicted that the granting of stocks options allows acting on the behavior and on the attitude of the managers. This way of compensation can seem more effective as far as it is not bound to an accounting data and is not an immediate compensation. For example, if the compensation depends on the market value, the interest of the manager will be to act on the information so as to maximize this value by revealing the favorable information and delaying the unfavorable information. In this way, the manager can 
maximize his short-term compensation and neglect the future consequences of his behavior on the company. However, when the manager is paid by stocks options, he would be involved in the future of the firm. So, we should take into account in our analysis some contractual incentives to see if the investors include them in their behavioral process.

\section{Methodology of the study}

\subsection{Sample}

Our sample is constituted by 365 quoted American companies and observed from 1994 to 2005. Then, this search yielded 4380 American firm-year observations from the database Compustat. The repartition of the firms is summarized as follow:

\begin{tabular}{|c|l|c|c|}
\hline SIC code & \multicolumn{1}{|c|}{ Sectors } & Number of firms & percentage \\
\hline 13 & Oil and gas field services & 27 & $7 \%$ \\
20 & Foods & 14 & $4 \%$ \\
22 & Textile products & 71 & $8,5 \%$ \\
47 & Transportation services & 27 & $2 \%$ \\
51 & Wholesales & 91 & $7,5 \%$ \\
73 & Software & 50 & $25 \%$ \\
28 & Pharmaceutics and biotech & 55 & $14 \%$ \\
35 & Industrial machinery and computer equipment & 63 & $15 \%$ \\
36 & Electronics and Electrical & 36 & $17 \%$ \\
\hline \multicolumn{2}{|c}{ Total } & $\mathbf{3 6 5}$ & $\mathbf{1 0 0 \%}$ \\
\hline
\end{tabular}

In the collection of our data, we choose the firms which have at least nine observations concerning the variable of the intangible assets recognized by the balance sheet because it is not evident to find automatically this variable in a continue way. This criterion of choice limited considerably the number of the observations in this study but it avoids at the same time the existence of a bias on the estimators of the variables.

The firms of the sample are partitioned into two groups in order to validate ours hypotheses. The first five sectors (SIC code 13, 20, 22, 47 and 51) are considered as traditional sectors which don't based essentially on intangible expenses and noted as "group 0". The others sectors (SIC code $28,73,35,36$ ) are considered as high technology sectors which requiring intensive intangible expenses and noted as "group 1". The distinction between the traditional sectors and the sectors of high technologies was made on the basis of the previous empirical studies (Gu and Wang, 2003, Mohd Emad , 2005, Darrough and Ye, 2007).

The choice of the adopted classification was not made according to the intensity of intangible assets recognized in the financial reports such as many researches (Sougiannis, 1994, Rogers, 


\section{Macrothink}

International Journal of Accounting and Financial Reporting

ISSN 2162-3082 2012, Vol. 2, No. 1

2002, Ballester and al, 2003) but it was made according to the nature of the industry. In this way, we may avoid a bias due to many problems concerning the accounting treatment of intangibles.

\subsection{The choice of the variables}

The variables chosen are the following:

- The market price of the share (P): it is the price of the share in the closing date of the financial statements. Normally, the price observed on the market reflects immediately any available information;

- The accounting earnings (RC): by this variable, we try to control the relevance of the accounting earnings in the explanation of the market value of the company;

- The intangible assets recognized in the balance sheet (I_INTG): it is the total value of the intangible assets appearing in the balance sheet (such as patents, brands, licenses). Cazavan-Jeny (2002) indicated that the individualized intangible assets are not useful for the investors, reason for which we took the total book value of the intangible assets. Besides, the detailed information is not available continuously in the study period;

- The research and the development expenditures (RD): for the investors, this information is surrounded with uncertainty and it can contain, at the same time, successful and failing projects. Under the American accounting standards, the accounting information about the $R \& D$ does not allow to indicate the quality of these investments. In that case, the investor look for the other information susceptible to assist him in his decision-making process;

- The value of stocks option (OPTION): On the financial market, the appreciation of the information relative to the granting of stocks options by the market is in accordance with the hypothesis according to which this method of payment is a system of incentive reducing the agency costs existing in the firm and made converge the interests of the managers on the interests of shareholders. Consequently, this method of compensation increases the investor's confidence in the supplied information and, thus, it increases the informative value especially when it is about risky $\mathrm{R} \& \mathrm{D}$ projects;

- Total debts (LEV): this variable allows representing the level of financial constraints within the company. In fact, the level of the debts can be a sufficient motivation for the managers to adopt an opportunist behavior. This behavior is shown by an accounting manipulation due to the accounting choices or by a real manipulation (discretionary decision of the investments: decrease, increase or cut off). 


\section{$\triangle$ Macrothink}

\subsection{The regression models}

To test our central hypothesis and check the relevance of the accounting information in the stock market, we appeal to the following models:

$$
P_{i t}=\beta_{i}+\beta R C_{i t}+\varepsilon
$$

Model 1

$$
P_{i t}=\beta_{i}++\beta_{1} I_{-} I N T G_{i t}+{ }_{i t}+\beta_{2} I N T G_{i t} * D_{L E V}+\beta_{3} I N T G_{i t} * D_{O P T I O N}+\varepsilon_{i t}
$$

$$
P_{i t}=\beta_{i}+\beta_{1} R D_{i t}+\beta_{2} R D_{i t} * D_{L E V}+\beta_{3} R D_{i t} * D_{\text {OPTION }}+\varepsilon_{i t}
$$

Model 3

$P_{i t}$ : The share price in the closing date of the accounting year (31-December) of the company i during period $\mathrm{t}$;

$R C_{i t}$ : Net accounting earnings divided on the total assets of the balance sheet of the firm $\mathrm{i}$ during period $\mathrm{t}$;

$I_{-} I N T G_{i t}:$ Intangible assets recognized in the balance sheet divided on the total assets of the firm i during the period $\mathrm{t}$;

$R D_{\text {it }}:$ The R\&D expenditures recognized in the income statement divided on the total assets of the firm i during the period $t$;

$\mathrm{D}_{\mathrm{LEV}}$ : Dummy variable equals to 1 if the firm has a ratio «long-term debts on stockholders' equities» lower than the median value of this ratio. This means that the firm has a low contractual motivation; otherwise it will be equal to 0 . The median value is calculated for every year because we have a panel data;

$D_{\text {OPTION }}$ : Dummy variable equals to 1 if the firm has a ratio «value of stocks options on the total remuneration of the managers» upper to the median value of this ratio. This means that the firm has a strong implication of the managers; otherwise it will be equal to 0 . The median value is calculated for every year because we have a panel data;

$I N T G_{i t} * \mathrm{D}_{\mathrm{LEV}}:$ Interaction intended to represent the relevance of the intangible assets only for the firms which have a low ratio «long-term debt on stockholders' equities» (below the median value); 


\section{Macrothink}

International Journal of Accounting and Financial Reporting

ISSN 2162-3082 2012, Vol. 2, No. 1

$R D_{i t} * \mathrm{D}_{\mathrm{LEV}}$ : Interaction intended to represent the relevance of the $\mathrm{R} \& \mathrm{D}$ expenditures only for the firm which has a low ratio «long-term debts on stockholders' equities» (below the median value);

$I N T G_{i t} * \mathrm{D}_{\mathrm{OPTION}}:$ Interaction intended to represent the relevance of the intangible assets only firms having a ratio «value of stocks options on the total remuneration of the managers» upper to the median value;

$R D_{i t} * \mathrm{D}_{\mathrm{OPTION}}:$ Interaction intended to represent the relevance of the $\mathrm{R} \& \mathrm{D}$ expenditures only for the firms having a ratio «value of stocks options on the total remuneration of the managers» upper to the median value.

\section{Empirical findings}

\subsection{The relevance of the accounting information about the accounting earnings}

According to Foster (1986), the investors tend to accept the accounting figures (especially, the income statement) to which they attribute a significant power. The most recent researches noticed that the explanatory power of the accounting earnings was damaged due to a failure in the accounting treatment of intangible resources especially and the accounting conservatism. Consequently, we proceeded, in a first time, to a simple regression of the market value of the company on the accounting earnings before testing the informative contents of the accounting data relative to the intangibles (assets and expenditures) in a second time. 


\section{$\triangle$ Macrothink}

International Journal of Accounting and Financial Reporting

ISSN 2162-3082

Table 1 : Simple regression of the relevance of the accounting earnings on the total sample

$$
P_{i t}=\beta_{i}+\beta_{1} R C_{i t}+\varepsilon_{i t}
$$

\begin{tabular}{|l|l|l|l|}
\hline $\begin{array}{l}\text { Explanatory } \\
\text { variables }\end{array}$ & Cœfficient & $\mathrm{T}$ & significativity \\
\hline RC & 0,252 & 0,99 & $0,323 \mathrm{~ns}$ \\
Intercept & 19,736 & 41,22 & $0,000 * * *$ \\
\hline Adjusted $\mathrm{R}^{2}$ & \multicolumn{3}{|c|}{0,258} \\
F & $0,98 \mathrm{~ns}$ \\
$\mathrm{~N}$ & \multicolumn{3}{|c}{4363} \\
\hline
\end{tabular}

${ }^{* * *}$ : Significant at the level of $1 \% ;^{* *}$ : Significant at the level of $5 \%$;

*: Significant at the level of $10 \%$; (ns) : not Significant at the level of $10 \%$.

$\mathrm{P}$ : The share price; $\mathrm{RC}$ : accounting earnings divided on the total assets ; $\mathrm{N}$ : The number of the observations; $\mathrm{T}$ : Student test for each explanatory variable ; F : Fisher test for the all variables.

According to the table 1, we notice that the accounting earnings are not relevant in the determination of the market value of the company in the American context. In this sense, Lev (1989) mentioned that the relation between the stock market price and the revealed accounting earnings is representative of the relevance or the utility of this accounting information. When there is a strong relation, these accounting earnings are perceived by the market as being useful. Consequently, a bad relation between the prices and the accounting earnings reflects deficiencies in the accounting treatments.

Besides, the accounting earnings divulged by the firms of traditional sectors can be more useful in the financial place (Landsman and Maydew, 2002) because that the accounting rules do not raise acute distortion in the recording of the transactions and the events with regard to the nature of the activity, the growth rate (low rate) and the environmental changes (slow changes) of these sectors. In fact, the high-technology firms carry out some investments which produce profits a posteriori and in the long term. Thus, the lack of correspondence between loads and revenues involves a decline of the utility of the accounting earnings (Collins and al, 1994). Besides, the growth rate and the fast change in the high-technology activities finish by an inadequacy between the accounting rules and the phenomenon to be recorded (Lev and Zarowin, 1999). Consequently, we predict that the relevance of the 
accounting earnings will be more pronounced in the sectors characterized by a low technology.

Table 2 : Simple regression of the relevance of the accounting earnings on each group of firms

$$
P_{i t}=\beta_{i}+\beta_{1} R C_{i t}+\varepsilon_{i t}
$$

\begin{tabular}{|l|c|c|c|c|c|c|}
\hline \multirow{2}{*}{$\begin{array}{l}\text { Explanatory } \\
\text { variables }\end{array}$} & \multicolumn{3}{|c|}{ Group 0 } & \multicolumn{3}{c|}{ Group 1 } \\
\cline { 2 - 7 } RC & Coefficients & $\mathrm{T}$ & Signif & Coefficients & $\mathrm{T}$ & Signif \\
\hline Intercept & 8,024 & 5,24 & $0,000^{* * *}$ & 0,209 & 0,91 & $0,363 \mathrm{~ns}$ \\
\hline Adjusted $\mathrm{R}^{2}$ & 21,457 & 66,98 & $0,000^{* * *}$ & 0,711 & 19,4 & $0,000^{* * *}$ \\
& \multicolumn{3}{|c|}{0,525} & \multicolumn{3}{c}{0,242} \\
F & \multicolumn{3}{|c|}{$0,83 \mathrm{~ns}$} \\
$\mathrm{~N}$ & $27,44^{* * *}$ & & 3150 \\
\hline
\end{tabular}

${ }^{* * *}:$ Significant at the level of $1 \%{ }^{* *}:$ Significant at the level of $5 \%$;

* : Significant at the level of $10 \%$; (ns) : not Significant at the level of $10 \%$.

$\mathrm{P}$ : The share price; $\mathrm{RC}$ : accounting earnings divided on the total assets ; $\mathrm{N}:$ The number of the observations; T : Student test for each explanatory variable ; F : Fisher test for the all variables; group 0: firms of traditional sectors; group 1: high technology firms.

The empirical results of the table 2 show that the information about the accounting earnings allows to explain $52,5 \%$ of the global variation of the market value in the group of the companies of traditional sectors. This information has no explanatory power for the companies of high technologies and, consequently, the absence of significativity of the accounting earnings for the total sample (shown in the table 1) results from these companies of high technologies. These empirical results show that the accounting conservatism can pull the decrease of the relevance of the information about the accounting earnings (Ryan and Zarowin, 2003). In fact, the information about cash flows is more useful for the investors because it is less subject to the accounting rules as shown the table 3. 


\section{Macrothink

Table 3 : Simple regression of the cash flow relevance

$$
P_{i t}=\beta_{i}+\beta_{1} C F_{i t}+\varepsilon_{i t}
$$

\section{Panel A : total sample}

\begin{tabular}{|l|l|l|l|}
\hline $\begin{array}{l}\text { Explanatory } \\
\text { variables }\end{array}$ & Cofficient & $\mathrm{T}$ & significativity \\
\hline $\mathrm{CF}$ & 2,379 & 3,9 & $0,000 * * *$ \\
intercept & 19,736 & 41,72 & $0,000 * * *$ \\
\hline Adjusted $\mathrm{R}^{2}$ & \multicolumn{3}{|c|}{0,26} \\
F & \multicolumn{3}{|c|}{$15,23 * * *$} \\
$\mathrm{~N}$ & \multicolumn{3}{|c}{4374} \\
\hline
\end{tabular}

Panel B : Distinction between the group of the companies of traditional sectors and the companies of high technologies

\begin{tabular}{|c|c|c|c|c|c|c|}
\hline \multirow{2}{*}{$\begin{array}{l}\text { Explanatory } \\
\text { variables }\end{array}$} & \multicolumn{3}{|c|}{ Group 0} & \multicolumn{3}{|c|}{ Group 1} \\
\hline & Coefficients & $\mathrm{T}$ & Signif & Coefficients & $\mathrm{T}$ & Signif \\
\hline $\mathrm{CF}$ & 6,598 & 6,15 & $0,000 * * *$ & 2,125 & 3,48 & $0,001 * * *$ \\
\hline intercept & 19,055 & 63,42 & $0,000 * * *$ & 19,132 & 29,53 & $0,000 * * *$ \\
\hline Adjusted $\mathrm{R}^{2}$ & \multicolumn{3}{|c|}{0,523} & \multicolumn{3}{|c|}{0,243} \\
\hline $\mathrm{F}$ & \multicolumn{3}{|c|}{$37,82 * * *$} & \multicolumn{3}{|c|}{$12,12 * * *$} \\
\hline $\mathrm{N}$ & \multicolumn{3}{|c|}{1213} & \multicolumn{3}{|c|}{3149} \\
\hline
\end{tabular}

\footnotetext{
${ }^{* * *}:$ Significant at the level of $1 \% ;^{* *}$ : Significant at the level of $5 \%$;

: Significant at the level of $10 \%$; (ns) : not Significant at the level of $10 \%$.

$\mathrm{P}$ : The share price; $\mathrm{CF}$ : operating cash flows divided on the total assets ; $\mathrm{N}$ : The number of the observations; $\mathrm{T}$ : Student test for each explanatory variable ; F : Fisher test for the all variables; group 0: firms of traditional sectors; group 1: high technology firms.
} 


\section{Macrothink \\ International Journal of Accounting and Financial Reporting \\ ISSN 2162-3082 \\ 2012, Vol. 2, No. 1}

\subsection{The relevance of the accounting information about the intangible}

The empirical test of the relevance of the information about the recognized intangible assets (the table 4) showed that this information has no explanatory power of the value of the market (on the total sample). Only, the distinction between the groups revealed that this variable became significantly positive $(8,814)$ and explains $40 \%$ of the variation of the market value of the companies of traditional sectors. But, this variable remains not significant for the companies of high technologies. Consequently, we can explain this result by the fact that the investor considers the intangible assets recognized by the companies of high technologies are widely insufficient relatively to the reality of the whole created resources. This finding confirms the previous empirical results. Indeed, the investor recognizes and predicts the effect of the accounting conservatism on the accounting information published by the companies of high technologies. Besides, he is aware that the conservatism concerns essentially the intangible assets of the companies of high technologies.

Table 4: Simple regression of the relevance of the recognized intangible assets

$$
P_{i t}=\beta_{i}+\beta_{1} I_{-} I N T G_{i t}+\varepsilon_{i t}
$$

\section{Panel A : Total sample}

\begin{tabular}{|l|l|l|l|}
\hline $\begin{array}{l}\text { Explanatory } \\
\text { variables }\end{array}$ & Cofficients & $\mathrm{T}$ & significativity \\
\hline I_INTG & 1,606 & 1,77 & $0,077 \mathrm{~ns}$ \\
intercept & 0,188 & 0,55 & $0,579 \mathrm{~ns}$ \\
\hline Adjusted $\mathrm{R}^{2}$ & \multicolumn{3}{|c|}{$13,2 \%$} \\
F & \multicolumn{3}{|c}{$3,12 *$} \\
$\mathrm{~N}$ & & 4255 \\
\hline
\end{tabular}




\section{Mll Macrothink}

International Journal of Accounting and Financial Reporting ISSN 2162-3082

Panel B : Distinction between the group of the companies of traditional sectors and the companies of high technologies

\begin{tabular}{|c|c|c|c|c|c|c|}
\hline \multirow{2}{*}{$\begin{array}{l}\text { Explanatory } \\
\text { variables }\end{array}$} & \multicolumn{3}{|c|}{ Group 0} & \multicolumn{3}{|c|}{ Group 1} \\
\hline & Coefficients & $\mathrm{T}$ & Signif & Coefficients & $\mathrm{T}$ & Signif \\
\hline I_INTG & 8,814 & 2,42 & $0,016^{* *}$ & 0,385 & 0,71 & $0,479 \mathrm{~ns}$ \\
\hline intercept & $-1,501$ & $-2,66$ & $0,008 * * *$ & 0,575 & 1,3 & $0,195 \mathrm{~ns}$ \\
\hline Adjusted $\mathrm{R}^{2}$ & \multicolumn{3}{|c|}{0,40} & \multicolumn{3}{|c|}{0,128} \\
\hline $\mathrm{F}$ & \multicolumn{3}{|c|}{$5,85 * *$} & \multicolumn{3}{|c|}{$0,5 \mathrm{~ns}$} \\
\hline $\mathrm{N}$ & \multicolumn{3}{|c|}{1172} & \multicolumn{3}{|c|}{3071} \\
\hline
\end{tabular}

${ }^{* * *}$ : Significant at the level of $1 \%{ }^{* *}$ : Significant at the level of $5 \%$;

$*$ : Significant at the level of $10 \%$; (ns) : not Significant at the level of $10 \%$.

P : The share price; I_INTG : Intangibles assets recognized in the balance sheet divided on the total assets ; N : The number of the observations; $\mathrm{T}$ : Student test for each explanatory variable ; F : Fisher test for the all variables; group 0: firms of traditional sectors; group 1: high technology firms.

Contrary to the intangible assets recognized in the balance sheet, the American market estimates positively the R\&D expenditures which have a coefficient in the order of 0,501 for the companies of high technologies (table 5). However, in the French context where the both modes of accounting treatment are authorized and the capitalization is optional, Cazavan-Jeny and Jeanjean (2006) showed that the capitalized R\&D is negatively associated with stock market prices. These empirical results can reflect the anticipations of the users of the financial information who think that the managers used their opportunism in the choice of the capitalization of the R\&D expenditures. It is also possible that the managers are not capable to discriminate between the profitable and the unprofitable R\&D projects. Consequently, the only capitalization does not allow communicating to the market information about the chances of the success of the R\&D projects thus the necessity of the additional information which is capable to help the users in their decision. 


\section{Macrothink

Table 5 : Simple regression of the $R \& D$ relevance

$$
P_{i t}=\beta_{i}+\beta_{1} R D_{i t}+\varepsilon_{i t}
$$

\begin{tabular}{|l|l|l|l|}
\hline $\begin{array}{l}\text { Explanatory } \\
\text { variables }\end{array}$ & Cœfficients & $\mathrm{T}$ & significativity \\
\hline $\mathrm{RD}$ & 0,501 & 9,05 & $0,000 * * *$ \\
intercept & 2,095 & 2,98 & $0,003 * * *$ \\
\hline Adjusted $\mathrm{R}^{2}$ & \multicolumn{3}{|c|}{0,803} \\
F & & $81,82 * * *$ \\
$\mathrm{~N}$ & & 2812 \\
\hline
\end{tabular}

${ }^{* * *}$ : Significant at the level of $1 \% ;{ }^{* *}$ : Significant at the level of $5 \%$;

* : Significant at the level of $10 \%$; (ns) : not Significant at the level of $10 \%$.

$\mathrm{P}$ : The share price ; RD : R\&D expenditures divided on the total sales; $\mathrm{N}:$ The number of the observations (high technology firms); T : Student test for each explanatory variable ; F : Fisher test for the all variables.

Only, the relevance of the information about intangible investments supplied by the companies of high technologies can be determined according to the other information helping the investor in the decision-making. Consequently, we shall test the relevance by taking into account the financial constraint $\left(\mathrm{D}_{\mathrm{LEV}}\right)$ and the degree of the implication of the managers in the company $\left(\mathrm{D}_{\text {OPTION }}\right)$. The empirical findings are summarized in the table 6 and 7 as follow:

Table 6 : Multivariate regression of the relevance of the recognized intangibles assets

Panel A :

$$
P_{i t}=\beta_{i}+\beta_{2} I_{-} I N T G_{i t}+\beta_{3} I N T G_{i t} * D_{L E V}+\varepsilon_{i t}
$$

\begin{tabular}{|c|c|c|c|}
\hline $\begin{array}{l}\text { Explanatory } \\
\text { variables }\end{array}$ & Cœefficients & $\mathrm{T}$ & significativity \\
\hline$I \quad I N T G$. & $-2,385$ & $-1,07$ & $0,286 \mathrm{~ns}$ \\
\hline - it & 0,772 & 1,05 & $0,292 \mathrm{~ns}$ \\
\hline$I N T G_{i t} * \mathrm{D}_{\mathrm{LEV}}$ & 0,803 & 1,69 & 0,09 \\
\hline intercept & & & \\
\hline Adjusted $\mathrm{R}^{2}$ & \multicolumn{3}{|c|}{0,128} \\
\hline $\mathrm{F}$ & \multicolumn{3}{|c|}{$0,61 \mathrm{~ns}$} \\
\hline $\mathrm{N}$ & \multicolumn{3}{|c|}{3071} \\
\hline
\end{tabular}


Panel B : $P_{i t}=\beta_{i}+\beta_{2} I_{-} I N T G_{i t}+\beta_{5} I N T G_{i t} * D_{L E V}+\beta_{7} I N T G_{i t} * D_{O P T I O N}+\varepsilon_{i t}$

\begin{tabular}{|c|c|c|c|}
\hline Explanatory variables & Cœfficients & $\mathrm{T}$ & significativity \\
\hline \multirow{2}{*}{$I_{-} I N T G_{i t}$} & $-2,498$ & $-1,12$ & $0,264 \mathrm{~ns}$ \\
\hline & 0,780 & 1,07 & $0,285 \mathrm{~ns}$ \\
\hline \multirow{2}{*}{$I N T G_{i t} * \mathrm{D}_{\mathrm{LEV}}$} & 0,113 & 9,11 & $0,000 * * *$ \\
\hline & 0,805 & 1,70 & $0,09 * * *$ \\
\hline \multicolumn{4}{|l|}{$I N T G_{i t} * \mathrm{D}_{\mathrm{OPTiON}}$} \\
\hline \multicolumn{4}{|l|}{ intercept } \\
\hline Adjusted $\mathrm{R}^{2}$ & \multicolumn{3}{|c|}{0,202} \\
\hline $\mathrm{F}$ & \multicolumn{3}{|c|}{$31,49 * * *$} \\
\hline $\mathrm{N}$ & \multicolumn{3}{|c|}{3071} \\
\hline
\end{tabular}

**** Significant at the level of $1 \% ;{ }^{* *}:$ Significant at the level of $5 \%$;

* : Significant at the level of $10 \%$; (ns) : not Significant at the level of $10 \%$.

P : The share price; I_INTG : Intangibles assets recognized in the balance sheet divided on the total assets; $D_{\mathrm{LEV}}$ : dummy variable equal to 1 if the firm has a ratio " long-term debts on the stockholders' equities " lower than the median value of this ratio, otherwise it will be equal to 0 ; $\mathrm{D}_{\text {OPTION }}$ : dummy variable equal to 1 if the firm has a ratio "value of stocks option on the total payment for the leaders " upper to the median value of this ratio, otherwise it will be equal to $0 ; \mathrm{N}$ : The number of the observations ; $\mathrm{T}$ : Student test for each explanatory variable; F : Fisher test for the all variables. 


\section{Mll Macrothink \\ International Journal of Accounting and Financial Reporting \\ ISSN 2162-3082 \\ 2012, Vol. 2, No. 1}

Table 7 : Multivariate regression of the relevance of the R\&D expenditures

Panel A :

$$
P_{i t}=\beta_{i}+\beta_{1} R D_{i t}+\beta_{2} R D_{i t} * D_{L E V}+\varepsilon_{i t}
$$

\begin{tabular}{|l|c|c|c|}
\hline $\begin{array}{l}\text { Explanatory } \\
\text { variables }\end{array}$ & Cœefficients & $\mathrm{T}$ & significativity \\
\hline$R D_{\text {it }}$ & 1,462 & 52.89 & $0,000 * * *$ \\
& $-0,962$ & $-17,18$ & $0,000 * * *$ \\
$R D_{i t} * \mathrm{D}_{\mathrm{LEV}}$ & 1,624 & 2,36 & $0,018 * *$ \\
intercept & & & \\
\hline Adjusted $\mathrm{R}^{2}$ & & 0,81 & \\
$\mathrm{~F}$ & & $488,98 * * *$ \\
$\mathrm{~N}$ & & 2812 \\
\hline
\end{tabular}

Panel B :

$$
P_{i t}=\beta_{i}+\beta_{1} R D_{i t}+\beta_{2} R D_{i t} * D_{\text {OPTION }}+\varepsilon_{i t}
$$

\begin{tabular}{|l|l|l|l|}
\hline $\begin{array}{l}\text { Explanatory } \\
\text { variables }\end{array}$ & Cofficients & $\mathrm{T}$ & significativity \\
\hline$R D_{\text {it }}$ & 0,501 & 9,04 & $0,000 * * *$ \\
& 0,857 & 3,58 & $0,000 * * *$ \\
$R D_{i t} * \mathrm{D}_{\mathrm{OPTION}}$ & 1,616 & 2,25 & $0,025 * *$ \\
intercept & & & \\
\hline Adjusted $\mathrm{R}^{2}$ & & 0,806 & \\
$\mathrm{~F}$ & & $58,75 * * *$ \\
$\mathrm{~N}$ & & 2812 \\
\hline
\end{tabular}

${ }^{* * *}:$ Significant at the level of $1 \% ;{ }^{* *}:$ Significant at the level of $5 \%$;

* : Significant at the level of $10 \%$; (ns) : not Significant at the level of $10 \%$.

P : The share price; $R D: R \& D$ expenditures divided on the total sales; $\mathrm{D}_{\mathrm{LEV}}$ : dummy variable equal to 1 if the firm has a ratio " long-term debts on the stockholders' equities " lower than the median value of this ratio, otherwise it will be equal to 0 ; $\mathrm{D}_{\mathrm{OPTION}}$ : dummy variable equal to 1 if the firm has a ratio " value of stocks option on the total payment for the leaders " upper to the median value of this ratio, otherwise it will be equal to $0 ; \mathrm{N}$ : The number of the observations (high technology firms); $\mathrm{T}$ : Student test for each explanatory variable; F : Fisher test for the all variables. 
Table 7 : Multivariate regression of the relevance of the $R \& D$ expenditures (continued)

$$
\text { Panel C : } \quad P_{i t}=\beta_{i}+\beta_{1} R D_{i t}+\beta_{2} R D_{i t} * D_{L E V}+\beta_{3} R D_{i t} * D_{O P T I O N}+\varepsilon_{i t}
$$

\begin{tabular}{|c|c|c|c|}
\hline $\begin{array}{l}\text { Explanatory } \\
\text { variables }\end{array}$ & Cœefficients & $\mathrm{T}$ & significativité \\
\hline \multirow{2}{*}{$R D_{\text {it }}$} & 1,462 & 49,49 & $0,000 * * *$ \\
\hline & 0,859 & 3,59 & $0,000 * * *$ \\
\hline \multirow{2}{*}{$R D_{i t} * \mathrm{D}_{\mathrm{OPTION}}$} & $-0,963$ & $-17,18$ & $0,000 * * *$ \\
\hline & 1,143 & 1,62 & $0,10 *$ \\
\hline \multicolumn{4}{|l|}{$R D_{i t} * \mathrm{D}_{\mathrm{LEV}}$} \\
\hline \multicolumn{4}{|l|}{ intercept } \\
\hline Adjusted $\mathrm{R}^{2}$ & \multicolumn{3}{|c|}{0,813} \\
\hline $\mathrm{F}$ & \multicolumn{3}{|c|}{830,3 *** } \\
\hline $\mathrm{N}$ & \multicolumn{3}{|c|}{2812} \\
\hline
\end{tabular}

${ }^{* * *}:$ Significant at the level of $1 \% ;^{* *}:$ Significant at the level of $5 \%$;

* : Significant at the level of $10 \%$; (ns) : not Significant at the level of $10 \%$.

$\mathrm{P}$ : The share price; $\mathrm{RD}: \mathrm{R} \& \mathrm{D}$ expenditures divided on the total sales; $\mathrm{D}_{\mathrm{LEV}}$ : dummy variable equal to 1 if the firm has a ratio " long-term debts on the stockholders' equities " lower than the median value of this ratio, otherwise it will be equal to $0 ; \mathrm{D}_{\text {OPTION }}$ : dummy variable equal to 1 if the firm has a ratio " value of stocks option on the total payment for the leaders " upper to the median value of this ratio, otherwise it will be equal to $0 ; \mathrm{N}$ : The number of the observations (high technology firms); T : Student test for each explanatory variable; F : Fisher test for the all variables.

\subsubsection{The effect of the debts on the relevance}

According to the empirical results presented in the table 6, we notice that the coefficient of the recognized intangible assets is not significant for the companies of high technologies. A priori, the absence of the significativity can be attributed to two completely different explanations:

- the investor can perceive that the amount recorded in the balance sheet is not reliable to be relevant. Holthausen and Watts (2001) indicated that the managers can introduce noise and bias to make deceive the auditors and the market. This noise leads to errors in the measure of the intangible assets and, thus, it brings to see a coefficient which 


\section{$\Lambda$ Macrothink}

International Journal of Accounting and Financial Reporting

tends towards zero either not significant in the regression if other variables are introduced and measured without error. Because the coefficient of the recognized intangible assets is predicted to be positive, its trend towards zero or its none significativity involves the existence of the strong contractual motivations which can pull the violation of the reliability principle. If the firms having strong motivations overvalue assets or introduce of noise, the market capitalizes these assets in a low or negligible coefficient (Holthausen and Watts, 2001). The differences between the investors in the prediction of the biais of the evaluation or in the estimation of the noise indicate a lack of consensus susceptible to damage the principle of verifiability (Kallapur and Kwan, 2004);

- because that the accounting standards are restrictive in the recognition of the intangible assets, the investor can perceive that the amount recorded in the balance sheet is insufficient to anticipate future cash flows which formulate an important part of the market value of the company. Only, the investor can introduce others informations, such as the stocks options, to consider that the recognized intangible assets are effectively productive and capable to generate future cash flows and, thus, it become relevant.

We notice that the level of debts (low or high) has no effect on the investor in the evaluation of the relevance of the recognized intangible assets because there is no change either in the coefficient or in the significativity. The constraints put by the debts can act on the opportunist behavior of the managers. Only, the significativity of the interaction can be explained by the fact that the investor considers that the accounting manipulations of a period must be compensated by the movements of the same importance in the inverse sense for the next period. Indeed, the manager can be in front of a technical constraint of manipulation because the present decisions are going to influence and to orient the future decisions (Skinner, 1993). Besides, according to the hypothesis of Watts and Zimmerman (1986), the accounting manipulations do not influence stock market prices except when it bring to modify the anticipations of future cash flows. Consequently, we may accept the second explanation and consider that the information asymmetry leads to the under evaluation of the market stocks of the company. In the American context, the standards forbid the capitalization of the R\&D expenditures with the exception of the software sector as far as they allow only the capitalization of development costs. However, the most known companies of this sector indicated that, generally, the totality of the costs are putting in loads when they are realized because they cannot divide their expenses between the development and the research and they are not obliged to opt for a particular accounting choice (Chan and al, 2001). Thus, in the absence of an accounting alternative, if the manager tries to adopt an opportunist behavior, he cannot pass by an accounting manipulation but he can proceed to a real manipulation. This manipulation consists to decide to increase or to reduce the expenses with regard to the restrictive clauses and the financial constraints and, consequently, to act on future cash flows. According to Watts and Zimmerman (1986), the modification of future cash flows pulls the variation of stock market prices. 
Otherwise, according to the signaling theory, the investors can interpret high levels of debts as a signal of the good quality of the company and the high probability of the realization of future cash flows. In that case, the managers can indicate to the market the success of the R\&D projects by the increase of the debts. Conversely, a low level of debts can indicate that this expenditure has no capacity to generate future economic advantages.

The introduction of the interaction between the R\&D variable and the low level of financial constraints (or low contractual motivations) is significantly (at the level of $1 \%$ ) negative in the order of 0,926 . However, the coefficient of the $R \& D$ revealed by firms with strong and low financial constraints (by the total firms without classification according to the level of the financial constraints) is positive. This result confirms the signaling theory by the debts. So, with a low level of debts, the investors can consider that the committed R\&D projects have no high probability to generate future cash flows susceptible to improve the capacity of the company to honor its commitments and consequently they are going to have a negative reaction towards the information about the $R \& D$. Thus, if the manager continues to undertake $R \& D$ projects, in spite of the existence of the restrictive clauses and the risk of disclosure of the information to the creditors with the absence of the accounting choices, the investor reacts positively. In fact, the manager does not take all these risks which lead to the loss of its job and its reputation if he is not sure to realize future cash flows.

Besides, we can notice, according to our empirical results, that the investor takes into account the risk that the real management of the accounting earnings can be presented. In other words, the manager can avoid the restrictive clauses by the cut off or the decrease of the R\&D expenditures. Indeed, the normalizers do not offer the possibility of the capitalization of the R\&D expenditures to limit the accounting manipulation. Then, the market takes into account the risk of a real manipulation. Thus, the foundation of the arguments advanced by the normalizers misses solid bases. Recently and in the Italian context where regulators give the possibility of the capitalization, Markarian and al (2008) found that the restrictive clauses in the contracts of debts have no effect on the decision of the capitalization of the R\&D expenditures.

We conclude that the investor considers the R\&D expenditures put in loads as an asset capable to generate future cash flows which determine the market value of the firm. Besides, Kallapur and Kwan (2004) proposed that the fact of confirming the relevance of the accounting information insures an acceptable degree of its reliability. Thus, if their capitalization is allowed, the market is capable of determining the degree of their reliability.

\subsubsection{The effect of the granting of stocks options}

The intangible investment seems to be a field where the conflicts become more marked. In the absence of an effective control of the managers, this type of investment can strengthen the managerial latitude and, thus, the differences between the insiders and the outsiders in their interests. It is predicted that the convergence can be insured by a control system of the behavior of the managers such as the implementation of incentive compensation by the granting of stocks options. The stocks options find their theoretical justification essentially in 
the agency theory.

The information about the intangible investments can be surrounded by uncertainty of the realization of future economic advantages. Consequently, the investor can adjust his evaluation by taking into account the information about the stocks options granted to the managers. So, our empirical results confirm the effect of the granting of stocks options on the determination of the relevance of the information about the intangible investments. The coefficient of the intangible assets recognized by companies having only high levels of stocks options is significantly (at the level of $1 \%$ ) positive in the order of 0,113 . Thus, the market appreciates the productivity of these assets and, consequently, their relevance when the managers hold a part of the capital of their company. Knowing that our sample is a sample of companies with strong opportunity of growth, Hutchinson and Gul (2006, p. 278) confirmed that « the firms with growth opportunities and executives share option plans are associated with better firm performance ». The performance is measured by the stocks returns realized by Australian companies.

Also, the R\&D coefficient, for the companies having a level of stocks options above the median, is 0,857 and significant at the level of $1 \%$. Besides, this coefficient is more raised than that given by the $R \& D$ of all the companies $(0,501)$. The $R \& D$ investment represents an unsafe investment and its profitability is in the long-term and, thus, it is associated with a high degree of risk. Only, if the managers are implied in this risk, the investor estimates favorably these expenditures. Indeed, they can, on one hand, act on the risk bound to the $R \& D$ projects and, on the other hand, increase the certainty of generation of the future economic advantages due to their adequate strategic decisions. Suitably to our results, Hutchinson and Gul (2006, p. 278) noted that « the combination levels of options and high growth opportunities are expected to lead to lower agency costs and better firm performance because it is this fundamental relationship that leads to executives undertaking risky future investment opportunities with positive outcomes ».

In the light of the found empirical results, we confirm our hypothesis which stipulates that the accounting information about the intangible (assets and expenses) have an informative value on the market. Besides, the investor uses determining factors (debts and compensation) as a condition for the relevance of this information as far as he is aware of the failure of many accounting rules.

In the same way, it was noted by Anagnostopoulou and Levis (2008) that it could be useful, before estimating the relation between the $R \& D$ and the market performance, to having some knowledge of the way with which the R\&D influences future operational (or economic) performance. This last relation can reduce the uncertainty of the investors and, consequently, it influences the market valuation. So, we found that the way of compensation, which affects the relation between the $R \& D$ and the future economic performance, affects also their relation with the market performance. Consequently, stocks options granted to the managers constitute a signal of the quality of the $R \& D$ given to the market. 


\section{Conclusion}

Firstly, we showed that, on the total sample, the information about the accounting earnings is not relevant in the explanation of the value of the share. Indeed, this relevance differs widely according to the nature of the sector. In sectors which are considered as traditional, the accounting standards are more capable to represent the transactions and the economic events (less information asymmetry more correspondence between the revenues and the expenses). Thus, the accounting earnings formulate a more synthetic and more representative measure of the economic performance and, consequently, they are more relevant in the market evaluation with regard to those revealed by the high-technology firms. So, the change in the economic conditions must be accompanied by a revision of the accounting standards to sustain the utility of the accounting measures.

Our empirical findings assist enormously the accounting normalizers by supplying them empirical evidence on the relevance of the information about the intangible investments. This relevance is moderated by others informations that the investor considers in his evaluation process. These informations tied to the signaling theory and the agency theory. The agency theory is based on the hypothesis according to which the risk averse investor is capable to anticipate, rationally and without biais, the incidence of the agency relations to the future value of the company. Consequently, these agency relations can influence the relevance of the accounting information.

Besides, the accounting normalizers prefer the reliability than the relevance. But, we remark that this arbitrage in favour of the reliability is not empirically quantifiable (Barth and al, 2001). Indeed, the accounting normalizers would consider several factors which can influence and determine the relevance and the reliability (Holthausen and Watts, 2001, Watts, 2002). Also, the normalizers must remind that in the absence of signaling by the accounting choices, the investor will seek other signals susceptible to help him in his decision-making process.

In the field of the intangible investments, the regulators consider that the accounting alternatives constitute a source of discretionary manipulation and, thus, a source of violation of the principle of reliability. According to the regulators, the absence of the accounting choices and the existence of the restrictive rules assure this reliability. Only, the study of the relevance according to the financial constraints, as motivation of manipulation, show that there isn't a change in the coefficient of the intangible assets recognized by the balance sheet. Otherwise, the investor judges that the value of these assets is reliable but this information remains widely insufficient to modify its predictions. However, in the absence of the accounting choices, a low level of financial constraints transmit to the market a signal of the failure of the R\&D projects (negative coefficient) because it is predicted that these projects will be unable to realize sufficient future cash flows to honor the financial commitments of the company.

Besides, the investors consider that the manager's effort and the degree of their implication may act on the uncertainty and, consequently, on the risk. This risk is considered by the 


\section{I Macrothink}

International Journal of Accounting and Financial Reporting

ISSN 2162-3082

2012, Vol. 2, No. 1

normalizers as obstacle in front of the reliability of measure of intangible assets. However, this risk is not absolute but it can be moderated by the managers. By introducing the stocks options into our analysis of the relevance, we found that the information about the recognized intangible assets and the R\&D expenditures is well appreciated by the market for the firms which grant more stocks options. So, the granting of stocks options represents a signal to the market on the efficiency of the managers and their implication in the risk of the committed investments.

\section{References}

- Anagnostopoulou, S.C., and Levis, M., R\&D and performance persistence : Evidence from the United Kingdom, The International Journal of Accounting, Vol 43, 2008, p. 293-320 ;

- Ballester, M., Garcia-Ayuso, M., and Livnat, J., The economic value of the RD intangibles asset, European Accounting Review, Vol 12, № 4, 2003, p. 605-633;

- Ballow, J.J, Burgman, R., and Molnar, M.J., Managing for shareholder value: intangibles, future value and investment decisions, Journal of Business Strategy, Vol $25, N^{\circ} 3,2004$, p. 26-34;

- Ballot, G., Fakhfakh, F. and Taymaz, E., Firm's human capital, R\&D and performance : A study of french and Swedish firms, Labour Economics, Vol 8, 2001, p. 443-462;

- Barth, M.E., Beaver, W.H., and Landsman, W.R., The relevance of the value relevance literature for financial accounting standard setting, Journal of Accounting and Economics Vol 31, $\mathrm{N}^{\circ} 1-3,2001$, p. 77-104 ;

- Callen, J.L., and Morel, M., The valuation relevance of R\&D expenditures : Time series evidence, International Review of Financial Analysis, Vol 14, 2005, p. 304-325;

- Cazavan-Jeny, A. and Jeanjean, T., The negative impact of R\&D capitalization : A value relevance approach, European Accounting Review, Vol 18, $\mathrm{N}^{\circ} 1$, 2006, p. 37-61;

- Cazavan-Jeny, A., Le ratio Market-to-Book et la reconnaissance des immatériels : Une étude du marché français, Comptabilité Contrôle Audit, Vol 10, º2, 2002, p. 99-124 ;

- Chan, L.K.C., Lakonishok, J., and Sougiannis, T., The stock market valuation of research and development expenditures, Journal of Finance, Vol 56, $\mathrm{N}^{\circ}$ 6, 2001, p. 2431-2456;

- Chauvin, K.W., and Hirschey, M., Advertising, R\&D expenditures and market value of the firm, Financial Management, Vol 22, N 4, 1993, p. 128-140 ; 


\section{Mll Macrothink}

International Journal of Accounting and Financial Reporting

ISSN 2162-3082

2012, Vol. 2, No. 1

- Collins, D.W., Kothari, S.P., Shanken, J., and Sloan, R.G., Lack of timeliness and noise as explanation for low contemporaneous return earnings association, Journal of Accounting and Economics, Vol 18, $\mathrm{N}^{\circ} 3,1994$, p. 289-324 ;

- Darrough, M., et Ye, J., Valuation of loss firms in a knowledge-based economy, Review of Accounting Studies, Vol 93, N 1, 2007, p. 61-93;

- Ding, Y., and Stolowy, H., Capitalisation des frais de R\&D en France : Déterminants et pertinence, 24th Annual Meeting of the French Accounting Association, Mars 2003;

- Foster, G., Financial statement analysis, Prentice Hill, Englewood Cliffs, USA, 1986 ;

- Garcia-Ayuso, M., Campos, M.I., and Molina, G.S., Fundamental analysis and human capital: Empirical evidence on the relationship between variables the quality of human resources and fundamental accounting variables, Journal of Human Resource Costing and accounting, $\mathrm{Vol} 5, \mathrm{~N}^{\circ} 1,2001$, p. 45-57 ;

- Goodwin, J., and Ahmed K., Longitudinal value relevance of earnings and intangible assets: Evidence from Australian firms, Journal of International Accounting, Auditing and Taxation, Vol 15, 2006, p. 72-91 ;

- Hall, B.H., and Oriani, R., Does the market value R\&D investment by European firms? Evidence from a panel of manufacturing firms in France, Germany and Italy, International Journal of Industrial Organization , Vol 24, 2006, p. 971-993 ;

- Holthausen, R.W., and Watts, R.L., The relevance of the value relevance literature for financial accounting standard setting, Journal of Accounting and Economics, Vol 31, 2001, p. 3-75;

- Hsu, L.T., and Jang, S.C., Advertising expenditure, intangible value and risk : A study of restaurant companies, International Journal of Hospitality Management, Vol 27, 2008, p.259-267 ;

- Hutchinson, M., and Gul, F., The effects of executive share options and investment opportunities on firms accounting performance: Some Australian evidence, The British Accounting Review, Vol 38, 2006, p. 277-297 ;

- Kallapur, S., and Kwan, S., The value relevance and reliability of brand assets recognized by UK firms, The Accounting Review, January, Vol 79, $\mathrm{N}^{\circ}$ 1, 2004, p. 151-172;

- Landsman, R.W., and Maydew, E.L., Has the information content of quarterly earnings announcement declined in the past three decades, Journal of Accounting Research, Vol 40, N³, 2002, p. 797-808;

- Lev, B., and Zarowin, P., The boundaries of financial reporting and how to extend 


\section{Macrothink}

International Journal of Accounting and Financial Reporting

ISSN 2162-3082 2012, Vol. 2, No. 1

them, Journal of Accounting Research, Vol 37, $\mathrm{N}^{\circ} 3$; 1999, p. 353-385 ;

- Lev, B., On the usefulness of earnings : Lessons and directions from two decades of empirical research, Journal of Accounting Research, Vol 27, 1989, p. 153-192 ;

- Lev, B., Nissim, D., and Thomas, J., On the informational usefulness of R\&D capitalization and amortization, Working Paper, New York University, March 2002 ;

- Lin, B.W., Information technology capability and value creation : Evidence from the US Banking industry, Technology in Society, Vol 29, 2007, p. 93-106 ;

- Markarian, G., Pozza, L., and Prencipe, A., Capitalization of R\&D costs and earnings management : Evidence from Italian listed companies, The International Journal of Accounting, Vol 43, 2008, p. 246-267 ;

- Mohd, E., Accounting for software development costs and information asymmetry, The Accounting Review, Vol 80, 2005, p. 1211-1231 ;

- Ohlson, J., Earnings, book values and dividend in security valuation, Contemporary Accounting Research, Spring, 1995, p. 661-687 ;

- Pentzalis, C., and Park, J.C., Equity market valuation of human capital and stock returns, Journal of Banking \& Finance, Vol 33, 2009, p. 1610-1623 ;

- Rogers, M., Firm performance and investment in RD and intellectual property, Melbourne Institute Working Paper $\mathrm{N}^{\circ}$ 15-02, August 2002 ;

- Ryan, S.G., and Zarowin, P.A., Why has the contemporaneous linear returns-earnings relation declined, The Accounting Review, Vol 78, $\mathrm{N}^{\circ}$ 2, 2003, p. 523-553;

- Singh, M., Faircloch, S., and Nejadmalayeri, A., Capital market impact of product marketing strategy: Evidence from relationship between advertising expenses and cost of capital, Journal of the Academy of Marketing Science, Vol 33, N 4, 2005, p. 432-444;

- Sougiannis, T., The accounting based valuation of corporate RD, The Accounting Review, Vol 69, N¹, 1994, p. 44-68;

- Shah, S.Z., Stark, A.W. and Akbar, S., The value relevance of major media advertising expenditures : Some U.K evidence, The International Journal of Accounting, Vol 44, 2009, p. 187-206;

- Skinner, D., The investment opportunity set and accounting procedure choice, Journal of Accounting and Economics, Vol 16, 1993, p. 85-95 ;

- Watts, R.L., conservatism in accounting, Working Paper, Simon School of Business, University of Rochester, 2002 ; 


\section{Macrothink \\ International Journal of Accounting and Financial Reporting \\ ISSN 2162-3082 \\ 2012, Vol. 2, No. 1}

- Watts, R.L., and Zimmerman, J.L., Positive accounting theory, Prentice-Hall, 1986 ; 